\title{
Gender and altruism in a random sample*
}

\author{
Anne Boschini ${ }^{\mathrm{a}}$, Anna Dreber ${ }^{\mathrm{b}}$, Emma von Essen $^{\mathrm{c}}$, Astri Muren $^{\mathrm{d}}$ and Eva \\ Ranehill ${ }^{\mathrm{e}}$
}

January 29, 2018

\begin{abstract}
:
We study gender differences in altruism in a large random sample of the Swedish population using a standard dictator game. Beside a baseline treatment we implement a priming treatment where participants are reminded of their gender, and two treatments with known male and female counterpart respectively. We find suggestive evidence that women are more altruistic than men only in the priming treatment. A post-hoc analysis of the effect of interviewer gender indicates that priming effects occur only in mixed-gender contexts.
\end{abstract}

JEL: C91; C93; J16

Keywords: Gender differences; Random sample; Dictator Game; Experiment

\footnotetext{
* We thank FORTE, the Jan Wallander and Tom Hedelius Foundation (Handelsbankens forskningsstiftelser) and the Knut and Alice Wallenberg Foundation for financial support. This paper was previously circulated under the title "Gender priming and altruism in a random sample".

${ }^{a}$ SOFI, Stockholm University, anne.boschini@ sofi.su.se

${ }^{\mathrm{b}}$ Department of Economics, Stockholm School of Economics, anna.dreber@hhs.se

c SOFI, Stockholm University, emma.von.essen@ sofi.su.se

${ }^{\mathrm{d}}$ Department of Economics, Stockholm University, astri.muren@ ne.su.se

e Department of Economics, Gothenburg University,eva.ranehill@economics.gu.se
} 


\section{Introduction}

Pro-sociality is integral to human beings, but it is also subject to social expectations. Prominent among these are gender stereotypes prescribing women to be other-regarding and generous and men to be competitive and aggressive (see e.g. Aguiar et al, 2009, and Rudman and Glick, 2001). A number of studies in psychology and economics point to priming and gender context as potential mechanisms of gender differences in behavior (see Steele and Aronson, 1995, Benjamin et al, 2010, Cadsby et al, 2011, and Boschini et al, 2012). Meanwhile, studies on dictator game giving, a measure that is often interpreted in terms of altruism, suggest that women if anything give more than men (see Engel 2015 for a meta-analysis). It is thus difficult to know to what extent these observed differences are due to deep-rooted differences in preferences or constructed in and by the social situation (see Bertrand, 2011).

In order to explore this further, we study gender differences in altruism by systematically varying gender context. We perform an experiment with a large random sample from the Swedish adult population. Our baseline condition is a regular dictator game (DG) with an anonymous recipient. Three treatment conditions vary gender context: a priming treatment where participants state their gender at the start of the experiment and two gender-of-counterpart treatments, where the recipient is either female or male.

There is a vast number of DG studies using student samples. These studies find that women are, if anything, more generous than men (see e.g. overviews in Croson \& Gneezy, 2009, and Engel, 2011). The handful of studies using representative samples finds similar results. While Carpenter et al (2008) observe no gender differences in donations in the US, and Cappelen et al (2015) find no gender differences in altruism in Norway, the results of Fisman et al (2014) suggest that women in the US give more than men do to an unknown other. These studies have different degrees of representativeness: Carpenter et al (2008) look at a community sample in Vermont, USA, 
Cappelen et al (2015) study a sample of individuals in Bergen, Norway and Fisman et al (2014) use the American Life Panel. We instead draw a simple random sample from the whole Swedish adult population. Moreover, none of the three studies explore gender context. In her survey of DG studies in the economics lab, Niederle (2016) concludes that once the gender of the recipient is controlled for, no gender differences in dictator game behavior remain, but no study using a representative sample investigates this dimension. This is our main contribution.

We describe our experiment and data in Section 2, results are presented in Section 3, in Section 4 we perform exploratory analysis using our data on gender of the interviewer, and Section 5 concludes.

\section{Data}

We combine the probabilistic sampling method with a randomized experiment. Statistics Sweden created a simple random sample of the Swedish adult population, and we randomly assigned the individuals of the sample to treatments. 997 participants aged 18-74 agreed to participate. Our sample is similar by gender, age, income and education to the Swedish adult population. In addition, we have a high response rate $(52,9 \%)^{1}$, and can detect no differences between non-response and response groups by gender and age (the two comparison variables we have access to). We therefore argue that we have a representative sample of the Swedish population. The experiment was mainly conducted through telephone interviews in October and November 2011. No systematic differences in socio-economic background were found between treatments. ${ }^{2}$

\footnotetext{
${ }^{1}$ As far as we know, the response rate is the highest of all representative experimental economics studies.

2 The Stockholm Ethical Review Board stated in June 2011 that our project did not need to undergo full ethical review. Data was collected by a professional polling company in Sweden.
} 
The interviews included eight behavioral decisions and additional questions, taking altogether 30 minutes. The DG is the focus of this paper. Data on other behaviors included in the experiment, such as risk preferences and competitiveness, are analysed in Boschini et al (2017). Before the experiment started, respondents were informed that, in addition to a SEK 100 show-up fee, one of the eight decisions would be randomly selected for payment. ${ }^{3} 32$ interviewers (17 men, 15 women) carried out the interviews.

The first decision was a DG; and all 997 participants are dictators. Dictators had 400 kronor to divide between themselves and a recipient. ${ }^{4}$ Participants in the baseline treatment were informed that they would be matched with another anonymous participant in the study. In the priming treatment, participants were additionally asked to state their gender immediately before the DG. In the female counterpart and male counterpart treatments, the gender of the recipient was revealed by using gendered pronouns. We included two control questions to make sure participants understood the setup. ${ }^{5}$

At the end of the interview, we collected socio-demographic information. Here we focus on three of these variables. Age is measured at the time of the experiment. Education is coded as one of four categories: 1 if less than 9 years of schooling; 2 if at least compulsory schooling (9-11 years of schooling); 3 if at least upper secondary school (12-14 years of schooling); and 4 if university (at least 15 years of schooling). Respondents were asked to indicate their income within the income brackets; less than 100000 SEK, 101-250k SEK; 251-375k SEK; 376-500k SEK, 501-750k SEK, 751-1000k SEK, and above $1000 \mathrm{k}$ SEK. In the estimations, the respondent's income is measured as the $\log$ of the average income in each income bracket $(50 \mathrm{k}$ and $1250 \mathrm{k}$ are extremes).

\footnotetext{
${ }^{3} 100$ kronor was approximately USD 15 at the time of the experiment.

${ }^{4} \mathrm{We}$ also had a random sample of the Swedish population taking the role of recipients in a postal survey.

${ }^{5}$ These were: 1) "If you choose to keep 200 kronor, how much does the other person get?" and 2) "If you choose to keep nothing, how much will the other person get?".
} 


\section{Results}

Table 1 presents OLS regressions for each treatment, with and without controlling for the three socio-demographic variables described above. We only include observations where dictators answered both control questions correctly (889 observations). ${ }^{6}$ All regressions cluster on interviewer.

Table 1. Gender differences in DG giving

\begin{tabular}{|c|c|c|c|c|c|c|c|c|}
\hline & $\begin{array}{c}\text { Baseline } \\
\text { (1) } \\
\end{array}$ & $\begin{array}{c}\text { Priming } \\
\text { (2) } \\
\end{array}$ & $\begin{array}{c}\text { Female } \\
\text { Counterpart } \\
(3)\end{array}$ & $\begin{array}{c}\text { Male } \\
\text { Counterpart } \\
\text { (4) } \\
\end{array}$ & $\begin{array}{c}\text { Baseline } \\
(5) \\
\end{array}$ & $\begin{array}{c}\text { Priming } \\
(6) \\
\end{array}$ & $\begin{array}{c}\text { Female } \\
\text { Counterpart } \\
(7) \\
\end{array}$ & $\begin{array}{c}\text { Male } \\
\text { Counterpart } \\
(8) \\
\end{array}$ \\
\hline Female & $\begin{array}{c}6.995 \\
(10.81)\end{array}$ & $\begin{array}{l}21.68^{*} \\
(9.738)\end{array}$ & $\begin{array}{l}-7.727 \\
(17.69)\end{array}$ & $\begin{array}{c}21.18 \\
(11.34)\end{array}$ & $\begin{array}{c}6.420 \\
(10.48)\end{array}$ & $\begin{array}{l}25.07^{*} \\
(10.63)\end{array}$ & $\begin{array}{c}-3.652 \\
(20.01)\end{array}$ & $\begin{array}{c}17.18 \\
(12.49)\end{array}$ \\
\hline Age & & & & & $\begin{array}{l}0.0947 \\
(0.472)\end{array}$ & $\begin{array}{l}0.0411 \\
(0.508)\end{array}$ & $\begin{array}{c}0.166 \\
(0.557)\end{array}$ & $\begin{array}{c}0.182 \\
(0.492)\end{array}$ \\
\hline Education & & & & & $\begin{array}{c}-3.378 \\
(2.781)\end{array}$ & $\begin{array}{c}-7.256^{* *} \\
(2.295)\end{array}$ & $\begin{array}{c}1.209 \\
(4.730)\end{array}$ & $\begin{array}{l}-0.289 \\
(2.439)\end{array}$ \\
\hline Income & & & & & $\begin{array}{l}-18.16 \\
(9.369)\end{array}$ & $\begin{array}{c}6.291 \\
(8.735)\end{array}$ & $\begin{array}{c}7.248 \\
(11.33)\end{array}$ & $\begin{array}{l}-2.897 \\
(8.738)\end{array}$ \\
\hline Constant & $\begin{array}{l}124.8^{* * *} \\
(8.468)\end{array}$ & $\begin{array}{c}117.7 * * \\
(8.554)\end{array}$ & $\begin{array}{c}133.7^{* *} \\
(12.06)\end{array}$ & $\begin{array}{l}114.4^{* * *} \\
(7.078)\end{array}$ & $\begin{array}{c}387.9 * * \\
(108.2)\end{array}$ & $\begin{array}{c}130.0 \\
(103.9)\end{array}$ & $\begin{array}{c}20.01 \\
(122.4)\end{array}$ & $\begin{array}{c}146.5 \\
(86.19)\end{array}$ \\
\hline $\begin{array}{l}\text { Obs. } \\
\mathrm{R}^{2}\end{array}$ & $\begin{array}{c}241 \\
0.001\end{array}$ & $\begin{array}{c}228 \\
0.013\end{array}$ & $\begin{array}{c}191 \\
0.001\end{array}$ & $\begin{array}{c}229 \\
0.012\end{array}$ & $\begin{array}{c}229 \\
0.034\end{array}$ & $\begin{array}{c}222 \\
0.043\end{array}$ & $\begin{array}{c}182 \\
0.008\end{array}$ & $\begin{array}{c}219 \\
0.009\end{array}$ \\
\hline
\end{tabular}

Robust standard errors in parentheses, clustered on interviewer.

$$
* * \mathrm{p}<0.01 \text { and } * \mathrm{p}<0.05 \text {. }
$$

We find suggestive evidence that female dictators give more than males in the priming treatment - in column (6) Female has a standardized beta of 0.133 and a p-value of 0.049 . There is no suggestive evidence of a gender difference in any other treatment. Moreover, dictator game giving does not seem to vary systematically with socioeconomic variables. ${ }^{7}$

\footnotetext{
${ }^{6}$ The results are robust to also including the respondents who did not answer the control questions correctly.

${ }^{7}$ The results are robust to variation in the definition of socio-demographic variables and to only including a full set of controls- see Appendix Tables A2-A3.
} 
When comparing the Female coefficient between treatments there are no significant differences in altruism, neither between any two treatments nor when comparing one treatment against all the others - see Table A4. Thus, dictator behavior in the priming treatment does not differ substantially from that in the other treatments. Table 2 presents the results with and without controls when all the treatments are pooled. This suggests that the result with a p-value of 0.049 above should be interpreted with some caution.

Table 2. Gender differences in DG giving when all the treatments are pooled

\begin{tabular}{l|cc}
\hline & $\begin{array}{c}\text { All } \\
\text { treatments } \\
(1)\end{array}$ & $\begin{array}{c}\text { All } \\
\text { treatments } \\
(2)\end{array}$ \\
\hline Female & 11.30 & 10.98 \\
& $(6.504)$ & $(6.623)$ \\
Age & & 0.150 \\
& & $(0.229)$ \\
Education & & -1.563 \\
Income & & $(4.384)$ \\
& & -2.780 \\
Constant & $122.0 * *$ & $(1.968)$ \\
& $(4.760)$ & $(47.45)$ \\
Obs. & 889 & 852 \\
$\mathrm{R}^{2}$ & 0.003 & 0.008 \\
\hline
\end{tabular}

Robust standard errors in parentheses, clustered on interviewer. $* * \mathrm{p}<0.01$ and $* \mathrm{p}<0.05$.

\section{Post-hoc analysis}

In research on survey methods effects of the interviewer are often studied. ${ }^{8}$ The gender composition of interviewer and respondent in the telephone interview could affect the responses, which in turn could interact with our treatments, in light of the findings in Boschini et al (2012). Assuming the priming effect exists, we explore whether a single-gender versus a mixed-

\footnotetext{
${ }^{8}$ See e.g. Johnson et al (1997), Gong and Aadland (2011), and Vassallo et al (2015).
} 
gender context contributes to our understanding of the observed effect. We did not have a pre-analysis plan for this study that was conducted in 2011. To analyze interviewer effects is not something we had originally planned to look at, unlike the previous analysis (that however was not pre-specified exactly).

We did not randomly assign interviewers to respondents, but each interviewer was assigned different treatments. We have equal shares of female and male interviewers. ${ }^{9}$ In the treatments where the gender of the counterpart is known (3 and 4), we define the context as "mixed-gender" if the interviewer, interviewee and counterpart are not all of the same gender. The complementary category is the "single-gender" context where all individuals in the interview situation are of the same gender. Thus, the single-gender context is when interviewer, interviewee and counterpart are either all men or all women. In treatments 1 and 2, where only interviewer and interviewee are identified by gender, we define the interview context to be "mixed-gender" interviewer and respondent are of opposite genders, and "single-gender" when interviewer and interviewee are either both men or both women.

In Table 3, we pool data from all four treatments and run three regressions separately for men and women in a mixed-gender context, and in a singlegender context, and the two combined (i.e., all observations). Each regression includes a dummy for the priming treatment and socio-demographic controls (and is clustered on interviewer).

The results in Table 3 the results suggest that priming does not significantly affect behavior outside of the mixed-gender context, and this holds for both men and women. More precisely, this suggests that gender priming could have an effect when there is a mixed-gender context (making women more altruistic and men less altruistic), while it has no effect in the single-gender context.

\footnotetext{
${ }^{9}$ For information on the exact distribution of interviewers across treatments, see Table A1 in the Appendix.
} 
Table 3. DG giving in priming and mixed-gender vs. single-gender settings

\begin{tabular}{l|ccc|ccc|}
\hline & $\begin{array}{c}\text { MEN } \\
\text { Mixed- } \\
\text { gender } \\
(1)\end{array}$ & $\begin{array}{c}\text { Single- } \\
\text { gender }\end{array}$ & All & $\begin{array}{c}\text { WOMEN } \\
\text { Mixed- } \\
\text { gender } \\
\text { Priming }\end{array}$ & $\begin{array}{c}\text { Single- } \\
\text { gender }\end{array}$ & All \\
Age & $-31.46^{* *}$ & 17.54 & -5.637 & $31.76^{*}$ & -21.91 & 7.521 \\
& $(11.06)$ & $(13.81)$ & $(12.18)$ & $(13.44)$ & $(18.15)$ & $(13.06)$ \\
Education & 0.416 & $-1.408^{* *}$ & -0.362 & 0.815 & 0.373 & 0.663 \\
Income & $(0.389)$ & $(0.430)$ & $(0.339)$ & $(0.414)$ & $(0.509)$ & $(0.340)$ \\
& -3.417 & $-9.378^{* *}$ & $-5.769^{*}$ & 1.876 & -1.508 & 0.956 \\
Constant & $(3.528)$ & $(2.936)$ & $(2.793)$ & $(2.678)$ & $(3.451)$ & $(1.936)$ \\
& -5.939 & $15.07 *$ & 3.099 & -2.978 & -9.889 & -4.550 \\
Observations & $(8.690)$ & $(5.830)$ & $(6.017)$ & $(8.239)$ & $(11.13)$ & $(6.250)$ \\
R-squared & $229.7 *$ & 106.0 & $174.9 *$ & 102.0 & 265.6 & $143.9 *$ \\
\hline
\end{tabular}

Robust standard errors in parentheses, clustered on interviewer. $* * \mathrm{p}<0.01$ and $* \mathrm{p}<0.05$.

This is consistent with experimental research using student samples suggesting that the interaction of mixed-gender situations and gender priming makes gender identity more salient, and that this can create gender differences in altruism (see Cadsby et al, 2011, and Boschini et al, 2012). The gender gap in altruism in the mixed-gender context of the priming treatment is significant ( $p$ $<0.001$ and standardized beta $=-0.64)-$ see Table A5 in the Appendix. However, given the exploratory nature of this analysis the results should be interpreted with caution and need to be replicated in future studies.

\section{Conclusions}

In this study, we explore gender differences in altruism in a random sample of the Swedish population. We find little evidence of gender differences in altruism, with some suggestive evidence that women are only more altruistic than men when participants are primed with their gender. Our largely null results might be due to the specific country that we study: Sweden is one of the most gender equal countries of the world. However, while post-hoc, our 
results on single and mixed gender contexts have potential implications for the way gender differences are studied in experimental economics. Given the exploratory nature of this analysis, replications are of course warranted before we can draw any inference regarding the importance of mixed-gender vs. single-gender context.

\section{References}

Aguiar, F., Brañas-Garza, P., Cobo-Reyes, R., Jimenez N. and L. M. Miller. 2009. "Are Women Expected to Be More Generous?". Experimental Economics 12 (1): 93-98. doi:10.1007/s10683-008-9199-z.

Benjamin, Daniel J, James J Choi, and A. Joshua Strickland. 2010. "Social Identity and Preferences". American Economic Review 100 (4): 1913-28. doi:10.1257/aer.100.4.1913.

Bertrand, Marianne, 2011. "New Perspectives on Gender" in O. Ashenfelter and D. Card, Eds., Handbook of Labor Economics 4B, 1543-1590.

Boschini, Anne, Astri Muren, and Mats Persson. 2012. "Constructing Gender Differences in the Economics Lab". Journal of Economic Behavior \& Organization 84 (3): 741-52. doi: 10.1016/j.jebo.2012.09.024.

Boschini, Anne, Anna Dreber, Emma von Essen, Astri Muren and Eva Ranehill. 2017. "Gender, risk preferences and competitiveness in a random sample of the Swedish population”, Stockholm University. mimeo.

Cadsby, C. Bram, Maroš Servátka, and Fei Song. 2010. “Gender and Generosity: Does Degree of Anonymity or Group Gender Composition Matter?'. Experimental Economics 13 (3): 299-308. doi:10.1007/s10683-0109242-8.

Cappelen, A. W., Nygaard, K., Sørensen, E. Ø. and B. Tungodden. 2015. "Social Preferences in the Lab: A Comparison of Students and a Representative Population". Scandinavian Journal of Economics 117(4): 1306-1326. doi: 10.1111/sjoe. 12114 
Carpenter, Jeffrey, Cristina Connolly, and Caitlin Knowles Myers. 2008. "Altruistic Behavior in a Representative Dictator Experiment". Experimental Economics 11(3): 282-98. doi:10.1007/s10683-007-9193-x.

Croson, Rachel and Uri Gneezy. 2009. "Gender Differences in Preferences." Journal of Economic Literature, 47(2): 448-74. doi: 10.1257/jel.47.2.448

Engel, Christoph. 2011. "Dictator games: a meta study". Experimental Economics 14 (4): 583-610. doi:10.1007/s10683-011-9283-7.

Fisman, Raymond, Pamela Jakiela, and Shachar Kariv. 2014. "The Distributional Preferences of Americans”. NBER Working Paper No. 20145.

Gong, Min and David Aadland. 2011. "Interview Effects in an Environmental Valuation Telephone Survey". Environmental and Resource Economics 49 (1): 47-64. doi: 10.1007/s10640-010-9423-0.

Johnson, T., Fendrich, M., Shaligram, C. and A. Garey. 1997. "A comparison of interviewer effects models in an RDD telephone survey of drug use. Proceedings of the Section on Survey Research Methods". American Statistical Association 887-892. http://www.amstat.org/sections/SRMS/Proceedings/y1997f.html.

Niederle, Muriel, 2016. “Gender” Handbook of Experimental Economics, second edition, Eds. John Kagel and Alvin E. Roth, Princeton University Press, 481-553.

Rudman, Laurie A. and Peter Glick, 2001, "Gender Biases in (Inter) Action: The Role of Interviewers' and Applicants' Implicit and Explicit Stereotypes in Predicting Women's Job Interview Outcomes". Journal of Social Issues 57 , 743-762. doi: 10.1111/0022-4537.00239.

Steele, Claude M., and Joshua Aronson. 1995. "Stereotype Threat and the Intellectual Test Performance of African Americans". Journal of Personality and Social Psychology 69 (5): 797-811. doi:10.1037/0022-3514.69.5.797.

Vassallo Rebecca, Gabriele B. Durrant, Peter W. F. Smith. 2015. "Interviewer effects on non-response propensity in longitudinal surveys: a multilevel modelling approach". Stat Soc Ser A Stat Soc. 178(1): 83-99. 


\section{Appendix}

Table A1. Interviewer gender and numbers of interviews

\begin{tabular}{|c|c|c|c|c|c|}
\hline \multirow{2}{*}{$\begin{array}{c}\text { Interviewer } \\
\text { id }\end{array}$} & \multirow{2}{*}{$\begin{array}{l}\text { Interviewer } \\
\text { gender }\end{array}$} & \multicolumn{4}{|c|}{ Number of interviews in } \\
\hline & & Baseline & Priming & Female c'part & Male c'part \\
\hline 1 & $M$ & 7 & 9 & 5 & 9 \\
\hline 2 & $F$ & 20 & 18 & 20 & 16 \\
\hline 3 & $M$ & 14 & 7 & 7 & 6 \\
\hline 4 & $F$ & 2 & 5 & 0 & 5 \\
\hline 5 & $M$ & 1 & 0 & 2 & 1 \\
\hline 6 & $M$ & 23 & 23 & 29 & 21 \\
\hline 7 & $F$ & 4 & 6 & 5 & 6 \\
\hline 8 & $M$ & 4 & 2 & 4 & 3 \\
\hline 9 & $F$ & 8 & 6 & 6 & 5 \\
\hline 10 & $M$ & 4 & 3 & 2 & 5 \\
\hline 11 & $M$ & 13 & 10 & 10 & 10 \\
\hline 12 & $F$ & 8 & 7 & 3 & 8 \\
\hline 13 & $M$ & 7 & 1 & 3 & 5 \\
\hline 14 & $F$ & 1 & 1 & 3 & 2 \\
\hline 15 & $F$ & 4 & 5 & 7 & 4 \\
\hline 16 & $M$ & 7 & 8 & 10 & 12 \\
\hline 17 & $M$ & 15 & 11 & 6 & 3 \\
\hline 18 & $M$ & 11 & 6 & 13 & 8 \\
\hline 19 & $M$ & 6 & 8 & 4 & 8 \\
\hline 20 & $F$ & 10 & 3 & 3 & 6 \\
\hline 21 & $M$ & 0 & 2 & 2 & 1 \\
\hline 22 & $M$ & 10 & 15 & 7 & 12 \\
\hline 23 & $F$ & 13 & 8 & 2 & 15 \\
\hline 24 & $F$ & 4 & 9 & 5 & 7 \\
\hline 25 & $F$ & 4 & 11 & 6 & 14 \\
\hline 26 & $F$ & 17 & 19 & 14 & 13 \\
\hline 27 & $M$ & 25 & 27 & 15 & 29 \\
\hline 28 & $F$ & 2 & 3 & 2 & 1 \\
\hline 29 & $F$ & 0 & 0 & 1 & 0 \\
\hline 30 & $M$ & 10 & 8 & 10 & 8 \\
\hline 31 & $F$ & 4 & 5 & 5 & 5 \\
\hline 32 & $M$ & 7 & 2 & 7 & 6 \\
\hline Total & $15 F, 17 M$ & $101 F, 164 M$ & $106 F, 142 M$ & $82 \mathrm{~F}, 136 \mathrm{M}$ & $107 \mathrm{~F}, 147 \mathrm{M}$ \\
\hline
\end{tabular}


Table A2. Gender differences in DG giving: Main results with a constant number of observations per treatment

\begin{tabular}{|c|c|c|c|c|c|c|c|c|}
\hline & $\begin{array}{c}\text { Baseline } \\
\text { (1) } \\
\end{array}$ & $\begin{array}{l}\text { Priming } \\
\text { (2) }\end{array}$ & $\begin{array}{c}\text { Female } \\
\text { Counterpart } \\
(3) \\
\end{array}$ & $\begin{array}{c}\text { Male } \\
\text { Counterpart } \\
(4) \\
\end{array}$ & $\begin{array}{c}\text { Baseline } \\
\text { (5) }\end{array}$ & $\begin{array}{c}\text { Priming } \\
\text { (6) }\end{array}$ & $\begin{array}{c}\text { Female } \\
\text { Counterpart } \\
(7)\end{array}$ & $\begin{array}{c}\text { Male } \\
\text { Counterpart } \\
(8) \\
\end{array}$ \\
\hline Female & $\begin{array}{c}4.612 \\
(10.30)\end{array}$ & $\begin{array}{l}22.26^{*} \\
(9.655)\end{array}$ & $\begin{array}{c}-6.588 \\
(18.33)\end{array}$ & $\begin{array}{c}17.21 \\
(11.97)\end{array}$ & $\begin{array}{c}6.420 \\
(10.48)\end{array}$ & $\begin{array}{l}25.07 * \\
(10.63)\end{array}$ & $\begin{array}{l}-3.652 \\
(20.01)\end{array}$ & $\begin{array}{c}17.18 \\
(12.49)\end{array}$ \\
\hline Age & & & & & $\begin{array}{l}0.0947 \\
(0.472)\end{array}$ & $\begin{array}{l}0.0411 \\
(0.508)\end{array}$ & $\begin{array}{c}0.166 \\
(0.557)\end{array}$ & $\begin{array}{c}0.182 \\
(0.492)\end{array}$ \\
\hline Education & & & & & $\begin{array}{c}-3.378 \\
(2.781)\end{array}$ & $\begin{array}{c}-7.256^{* *} \\
(2.295)\end{array}$ & $\begin{array}{c}1.209 \\
(4.730)\end{array}$ & $\begin{array}{l}-0.289 \\
(2.439)\end{array}$ \\
\hline Income & & & & & $\begin{array}{l}-18.16 \\
(9.369)\end{array}$ & $\begin{array}{c}6.291 \\
(8.735)\end{array}$ & $\begin{array}{c}7.248 \\
(11.33)\end{array}$ & $\begin{array}{l}-2.897 \\
(8.738)\end{array}$ \\
\hline Constant & $\begin{array}{c}125.8 * * \\
(8.737)\end{array}$ & $\begin{array}{l}117.3 * * \\
(8.643)\end{array}$ & $\begin{array}{l}134.5 * * \\
(12.39)\end{array}$ & $\begin{array}{c}115 * * \\
(7.264)\end{array}$ & $\begin{array}{c}387.9 * * \\
(108.2)\end{array}$ & $\begin{array}{c}130.0 \\
(103.9)\end{array}$ & $\begin{array}{c}20.01 \\
(122.4)\end{array}$ & $\begin{array}{c}146.5 \\
(86.19)\end{array}$ \\
\hline $\begin{array}{l}\text { Obs. } \\
\mathrm{R}^{2}\end{array}$ & $\begin{array}{c}229 \\
0.001\end{array}$ & $\begin{array}{c}222 \\
0.014\end{array}$ & $\begin{array}{c}182 \\
0.001\end{array}$ & $\begin{array}{c}219 \\
0.008\end{array}$ & $\begin{array}{c}229 \\
0.034\end{array}$ & $\begin{array}{c}222 \\
0.043\end{array}$ & $\begin{array}{c}182 \\
0.008\end{array}$ & $\begin{array}{c}219 \\
0.009\end{array}$ \\
\hline
\end{tabular}

Dependent variable is the amount given. Robust standard errors in parentheses. $* * \mathrm{p}<0.01$ and $* \mathrm{p}<0.05$. 
Table A3. Gender differences in DG giving: Main results with differently specified socio-demographic controls

\begin{tabular}{|c|c|c|c|c|}
\hline & $\begin{array}{c}\text { Baseline } \\
\text { (1) }\end{array}$ & $\begin{array}{c}\text { Priming } \\
\text { (2) }\end{array}$ & $\begin{array}{c}\text { Female } \\
\text { Counterpart } \\
(3)\end{array}$ & $\begin{array}{c}\text { Male } \\
\text { Counterpart } \\
(4)\end{array}$ \\
\hline Female & $\begin{array}{c}6.237 \\
(11.17)\end{array}$ & $\begin{array}{c}22.76 \\
(12.65)\end{array}$ & $\begin{array}{c}-9.394 \\
(17.56)\end{array}$ & $\begin{array}{c}17.97 \\
(11.65)\end{array}$ \\
\hline Age & $\begin{array}{l}0.0299 \\
(0.476)\end{array}$ & $\begin{array}{c}0.00754 \\
(0.465)\end{array}$ & $\begin{array}{c}0.573 \\
(0.498)\end{array}$ & $\begin{array}{c}0.265 \\
(0.432)\end{array}$ \\
\hline EducLow & $\begin{array}{c}0.945 \\
(23.09)\end{array}$ & $\begin{array}{c}20.72 \\
(17.29)\end{array}$ & $\begin{array}{l}-38.07 \\
(21.00)\end{array}$ & $\begin{array}{c}1.381 \\
(19.04)\end{array}$ \\
\hline EducHigh & $\begin{array}{l}-9.621 \\
(20.12)\end{array}$ & $\begin{array}{l}-15.84 \\
(11.05)\end{array}$ & $\begin{array}{l}-14.70 \\
(20.43)\end{array}$ & $\begin{array}{l}-2.906 \\
(9.653)\end{array}$ \\
\hline IncLow & $\begin{array}{c}9.068 \\
(11.85)\end{array}$ & $\begin{array}{l}-13.96 \\
(13.58)\end{array}$ & $\begin{array}{c}-9.136 \\
(13.68)\end{array}$ & $\begin{array}{c}-15.19 \\
(17.60)\end{array}$ \\
\hline IncHigh & $\begin{array}{l}-20.01 \\
(19.67)\end{array}$ & $\begin{array}{l}-19.25 \\
(13.97)\end{array}$ & $\begin{array}{l}-15.85 \\
(19.43)\end{array}$ & $\begin{array}{l}-29.03 \\
(20.16)\end{array}$ \\
\hline Constant & $\begin{array}{l}127.6 * * \\
(21.96)\end{array}$ & $\begin{array}{l}131.8 * * \\
(25.22)\end{array}$ & $\begin{array}{l}128.3 * * \\
(31.49)\end{array}$ & $\begin{array}{l}118.1 * * \\
(24.14)\end{array}$ \\
\hline $\begin{array}{l}\text { Obs. } \\
\mathrm{R}^{2}\end{array}$ & $\begin{array}{c}241 \\
0.019\end{array}$ & $\begin{array}{c}228 \\
0.039\end{array}$ & $\begin{array}{c}191 \\
0.026\end{array}$ & $\begin{array}{c}229 \\
0.025\end{array}$ \\
\hline
\end{tabular}

Dependent variable is the amount given. Education is defined as low if the respondent has less than 10 years of schooling, and high if the respondent has at least 15 years of schooling. Income is low if less than 250k and high if exceeding $375 \mathrm{k}$ SEK. Robust standard errors in parentheses. ${ }^{* *} \mathrm{p}<0.01$ and $* \mathrm{p}<0.05$. 
Table A4. Gender differences in DG giving: Between treatment results

\begin{tabular}{|c|c|c|c|c|c|c|c|}
\hline & \multicolumn{4}{|c|}{ One treatment vs. all others } & \multirow{2}{*}{$\begin{array}{c}\text { Priming } \\
\text { vs. } \\
\text { Baseline } \\
(5) \\
\end{array}$} & \multirow{2}{*}{$\begin{array}{c}\text { Fem. counter- } \\
\text { part vs } \\
\text { Baseline } \\
(6) \\
\end{array}$} & \multirow{2}{*}{$\begin{array}{c}\text { Male counter- } \\
\text { part vs } \\
\text { Baseline } \\
(7) \\
\end{array}$} \\
\hline & $(1)$ & $(2)$ & $(3)$ & (4) & & & \\
\hline Female & $\begin{array}{c}11.33 \\
(6.473)\end{array}$ & $\begin{array}{c}11.31 \\
(6.522)\end{array}$ & $\begin{array}{c}11.24 \\
(6.530)\end{array}$ & $\begin{array}{l}11.30 \\
(6.495)\end{array}$ & $\begin{array}{c}14.14 \\
(7.395)\end{array}$ & $\begin{array}{c}0.492 \\
(9.642)\end{array}$ & $\begin{array}{c}13.92 \\
(8.441)\end{array}$ \\
\hline Baseline & $\begin{array}{c}0.983 \\
(7.050)\end{array}$ & & & & & & \\
\hline Priming & & $\begin{array}{c}0.992 \\
(10.62)\end{array}$ & & & $\begin{array}{l}-0.0179 \\
(11.46)\end{array}$ & & \\
\hline Fem. counterpart & & & $\begin{array}{c}1.908 \\
(7.739)\end{array}$ & & & $\begin{array}{c}1.439 \\
(9.617)\end{array}$ & \\
\hline Male counterpart & & & & $\begin{array}{l}-3.685 \\
(6.080)\end{array}$ & & & $\begin{array}{l}-3.505 \\
(6.133)\end{array}$ \\
\hline Constant & $\begin{array}{l}121.8^{* * *} \\
(4.501)\end{array}$ & $\begin{array}{l}121.8^{* * *} \\
(6.112)\end{array}$ & $\begin{array}{c}121.7 * * \\
(5.150)\end{array}$ & $\begin{array}{l}123.0^{* * *} \\
(4.752)\end{array}$ & $\begin{array}{c}121.4^{* *} \\
(7.598)\end{array}$ & $\begin{array}{c}127.9 * * \\
(9.034)\end{array}$ & $\begin{array}{c}121.5^{* *} \\
(8.045)\end{array}$ \\
\hline Observations & 889 & 889 & 889 & 889 & 469 & 432 & 470 \\
\hline R-squared & 0.003 & 0.003 & 0.003 & 0.004 & 0.005 & 0.000 & 0.005 \\
\hline
\end{tabular}

Robust standard errors in parentheses. Standard errors clustered on interviewer. $* * \mathrm{p}<0.01$ and $* \mathrm{p}<0.05$. 
Table A5. Mean DG giving in the baseline and priming treatments by mixedgender context and single-gender context, for men and women

\begin{tabular}{|c|c|c|c|c|c|}
\hline & & Men & Women & $\begin{array}{l}\text { Kolmogorov- } \\
\text { Smirnov } \\
\text { (combined) }\end{array}$ & $\begin{array}{c}\text { Mann- } \\
\text { Whitney }\end{array}$ \\
\hline \multirow[t]{2}{*}{$\begin{array}{l}\text { Single- } \\
\text { gender }\end{array}$} & $\begin{array}{c}\text { Baseline } \\
\text { \# obs. }\end{array}$ & $\begin{array}{c}115.0 \\
132\end{array}$ & $\begin{array}{c}140.1 \\
88\end{array}$ & $P=0.593$ & $\mathrm{P}=0.0934$ \\
\hline & $\begin{array}{c}\text { Priming } \\
\text { \# obs. }\end{array}$ & $\begin{array}{c}130.6 \\
71\end{array}$ & $\begin{array}{c}124.6 \\
59\end{array}$ & $\mathrm{P}=1.000$ & $\mathrm{P}=0.8379$ \\
\hline \multirow[t]{2}{*}{$\begin{array}{l}\text { Mixed- } \\
\text { gender }\end{array}$} & $\begin{array}{c}\text { Baseline } \\
\text { \# obs. }\end{array}$ & $\begin{array}{c}129.3 \\
200\end{array}$ & $\begin{array}{c}128.1 \\
241\end{array}$ & $\mathrm{P}=1.000$ & $\mathrm{P}=0.7780$ \\
\hline & $\begin{array}{c}\text { Priming } \\
\text { \# obs. }\end{array}$ & $\begin{array}{c}97.8 \\
46\end{array}$ & $\begin{array}{c}156.2 \\
52\end{array}$ & $\mathrm{P}=0.041$ & $\mathrm{P}=0.0037$ \\
\hline
\end{tabular}

